the book of Genesis-namely, Genesis, i. 26. "Let us make man in our image, after our likeness." The fact that the book of Genesis is a composite work, and that it includes two versions of creation derived from separate sources has, of course, long been recognised by Biblical scholars. Moreinstructive than the above version is the different description of the creative act given in Genesis, ii. 7, "and the Lord God formed man of the dust of the ground, and breathed into his nostrils the breath of life; and man became a living soul". We should have expected, too, mention of the manner in which Eve came into being, and how the prediluvial population of the world had arisen from a single pair.

We are sure that Sir Ambrose Fleming would not wilfully misrepresent the case of his opponents ; yet there is no doubt he has been unfair to the Bishop of Birmingham. "There are," said Sir Ambrose in his lecture, "no sufficient reasons for declaring the evolutionary origin of the human race a definitely certain fact. Certainly none for assuring a general congregation in Westminster Abbey, as did Bishop Barnes, on Sunday, Sept. 25 , 1927, that "To-day there is among competent men of science unanimous agreement that man has been evolved from an ape-like stock'." In so far as anthropologists were unanimous in 1927 as they are to-day in regarding man as a product of evolution and not of special creation, we hold that the statement made by the Bishop of Birmingham was amply justified. We rejoice, too, to note that the new dean of St. Paul's, Dr. Matthews ${ }^{1}$, supports the evolutionary doctrine of man's origin and in opposition to Sir Ambrose Fleming sees no incompatibility between the doctrine of evolution and the precepts of Christianity.

${ }^{1}$ Daily Telegraph, Jan. 18, 1935. "Evolution and the Human Race."

\section{Malaria in Ceylon}

$\mathrm{T}^{\mathrm{n}}$ HERE is unfortunately no doubt about the serious nature of the epidemic of malaria in Ceylon. The telegrams in the Press report that in the affected provinces no less than 3,435 deaths from malaria and fever occurred during the month of December, compared with a monthly average of 531 for the first nine months of the year. It is admitted, however, that these figures are not final. It has been reported that there have been more than half-a-million cases of malaria, and if the death-rate was 5 per cent, that would give us something like 25,000 deaths.
The first need in an outbreak like this is medicine and food, and the Government of Ceylon has been in the happy position of being able to draw supplies of quinine from both India and Java. There is, however, another greatly complicating factor, and that is famine. The drought which has prevailed-and is generally regarded as the cause of the epidemic-has led to a serious failure of crops, and, even if the rain had not failed, the people themselves have been so weakened by disease that they have not been able to cultivate their fields. We may therefore expect that, in a people weakened by want of food and by malaria, this epidemic will be followed by a serious outbreak of dysentery and a rise in the general death-rate from all causes.

The epidemic itself has not been caused as epidemics frequently are-by the introduction of non-immune people into a malarial territory. The outbreak is in a part of Ceylon which is normally healthy. The new factor has in all probability been an increase in the number of mosquitoes. Among any healthy population in the tropics there is always a certain number of people carry. ing the infection; and when, as appears to be the case in Ceylon, there is a large increase in the number of mosquitoes, it is easy for the mosquito to acquire infection and to start a serious epidemic. Once a mosquito is infected it remains infected for life; and, further, as this epidemic is occurring among people who are not accustomed to malaria, the epidemic is so much the worse.

Valuable entomological work has been done in Ceylon by the Government Entomologist, but in view of this great epidemic there must be a full reinvestigation. Until we get that, everything is necessarily speculative.

One hypothesis is that, owing to the drought, rivers are not flowing so rapidly as they usually do, pools remain in the rocky and sandy beds, and $A$. culicifacies is breeding profusely. That may be so, but we must not forget that there are some thirty species of Anopheles in Ceylon and that they include species of the $A$. minimus group and A. maculatus, which in other countries are important carriers of malaria. A grave mistake might be made if a full investigation is not made into what mosquito, or mosquitoes, have been the active agents in producing this epidemic in the various parts of Ceylon to which the epidemic has spread.

Obviously the people of Ceylon were not 
prepared for a great epidemic ; it will be necessary for them to take stock of their position. The ancient cities buried in the jungle are a reminder that malaria is no new disease in Ceylon. Governing authorities should ask themselves: Have they used the knowledge that Ross gave them to the fullest possible extent, or have they made no special effort, thinking that nothing could be done?

Clearly some sort of inquiry will inevitably be held, but what is required is not so much a search for a scape-goat or an inquest, as a constructive scheme for the future, built on a sure scientific foundation.

\section{Reviews}

\section{Newton's Principia}

Sir Isaac Newton's Mathematical Principles of Natural Philosophy and his System of the World. Translated into English by Andrew Motte in 1729. The translations revised, and supplied with an Historical and Explanatory Appendix by Prof. Florian Cajori. Pp. xxxv +680 . (Cambridge: At the University Press, 1934.) 35s. net.

ADREW MOTTE'S translation of the "PrinA cipia" is not so well known as it deserves to be. It was supplied to his brother, the publisher, soon after Newton's death. One might expect it then to be no more than a publisher's hack work, of which we have so many dismal examples. But Motte appears to have understood the "Principia", and his language does not date noticeably, and never falls below a good level. The present work is really a republication of Motte, with some improvements, and-it is regrettable to add-one most serious omission.

Prof. Cajori died in 1930, so that the book has been seen through the press by Prof. R. T. Crawford, of the University of California, Berkeley. But the changes in Motte's text, the notes, and the work generally, is credited to Cajori. The notes seem to be complete, but might perhaps have been put into a compacter form, had the author lived. In their present shape, they give a certain number of references, but scarcely advance any of the subjects. Along with the "Principia" is a translation of the lectures given at Cambridge and called "The System of the World", which Prof. Cajori, apparently with good reason, also puts down to Motte. It is quite worth presenting, for, though it is not so complete as the "Principia", it is less guarded and less austere.

One distinct improvement upon Motte is found in printing the diagrams among the text, as they were in the various editions of the "Principia". Motte, no doubt in the interest of economy, collected them together and put them into folders. Most of Prof. Cajori's changes are modernisations. One requires to think a little, now, before one remembers the meaning of "sesquiplicate ratio" and the like. But nothing can be done to improve the awkward, old analysis, nor is Prof. Cajori quite consistent. Thus [quantitas] genita, retained by Cajori as "a genitum", is simply what we now call a function, and "square or cube sides" for "latera quadrata, latera cubica" is retained where the modern equivalent would be square root or cube root. Nor does he always correct Motte's mistranslations. In Newton's celebrated experiment upon apparent and absolute rotation, situla means a bucket, whereas Motte translates it a vessel, and Cajori retains this. It is a pity that the work did not fall into the hands of a stricter scholar.

But these are minor matters. The risk of a translation is that it may be more obscure than the original. The "Principia" was considered a hard book by people of the time, and Newton deliberately refused to make it more popular. In many places he wrote with the extremest compression. An example is the Second Definition, which runs "Quantitas motus est mensura ejusdem orta ex velocitate et quantitate materiae conjunctim". This figures here- scarcely changed from Motteas "The quantity of motion is the measure of the same, arising from the velocity and quantity of matter conjointly". This seems to me more obscure than the Latin original. The comma and the 'the's have spoiled it. As one pores over the original words, one reflects that Newton was a geometer, who said, when he pleased, everything at once, so that all parts of his statement must be taken together. Newton picked his words, and in many places one will prefer to see what Newton himself wrote, not what Motte or Cajori made of it.

Yet the book is a pleasant book, and to the large but not universal class who read English more easily than Latin, it presents distinct advantages in finding one's way about. It is doubtful whether it will be read by so-called 'students', which may be taken to mean young men in a hurry. The great defect of the book is that it has not an index. A fairly good index was added to the second edition, and Motte gave one too, but Cajori has suppressed it. There are multitudes of details dealt with here, some of them most unexpected, such as remarks upon the finite velocity of light, and significant both for what Newton said, and what he did not say. In fact, the "Principia" must be easily the most 